\title{
Highest and Best Use: The Evolving Paradigm
}

\author{
Mark G. Dotzour* \\ Terry V. Grissom** \\ Crocker H. Liu*** \\ Thomas Pearson****
}

\begin{abstract}
Highest and Best Use is often identified as the key concept supporting real estate use and value decisions. However, at best the concept has received ambiguous if not conflicting consideration as to its relevance in the literature of economics, finance, real estate, appraisal and other areas of study concerned with land use decisions and valuation. This paper addresses this ambiguity and identifies the theoretical premises of Highest and Best Use as employed in the various land use disciplines. The theoretical foundations as they ase syuthesized form the hasis of a formal constrained optimization model for land ase decisions. The model's logic identifies the need to include the cost of eapital and location along with the physical, legal, infrastructure and market parameters discussed in the bulk of the economic and appraisal literature (including courses and professional practice). The financial and locational variables are needed in order to advance the use paradigm to fit the current context of problems facing real estate decisionmakers.
\end{abstract}

The motivation for this research is derived from Dasso and Woodward's [14] statement that highest and best use (HBU) promises to provide an acceptable social ethic for real estate and implies the need for efficient real estate markets for optimal allocation of resources. Yet despite HBU's potential as a central paradigm of real estate and related land use studies, numerous issues of conflict exist in the development of land use models, as pointed out in the research of Grissom [23] and Vandell [54]. As described by Vandell [54], general faults occur in the HBU model on an analytical basis. Vandell states:

Economic theory derives its definitions through formal models. The concepts which evolve ...then have precise definitions which follow directly from the assumptions made and allow consistent estimation by different analysts. This precision also should be the goal of valuation theory, which is economic theory applied to real estate.

The objective of this research is to develop a formal model to enable the analytical consistency suggested by Vandell. This goal is advanced by identifying the array of

*Department of Finance, Real Estate and Decision Sciences, The Wichita State University, Wichita, Kansas $67208-1595$.

**Real Estate Center, Texas A\&M Unıversity, College Station, Texas 77843-2115

***DDepartmene of Finance, 900 Tisch Hall, The Stern School of Business. New York University. New York. New York 10003 .

*****Melson \& Associates, 3300 Oaklawn Avenue, Dallas. Texas

Date Revsed--March 25, 1990; Accepted-April 15, 1990. 
assumptions considered in the debates on land use models and incorporating them into a formal economic decision model of constrained optimization.

Despite HBU's perceived central position in real estate decisions, ${ }^{\dagger}$ the concept is a paradox in real estate studies. Perusal of real estate. finance and economic literature indicates anything but a consensus on its place in the decision process. This lack of consensus may be because $\mathrm{HBU}$ is employed as a process and not a formalized model. The concept of HBU as a process rather than a formalized decision model is evident in the arguments put forth by Vandell [54], Grissom [23], Graaskamp [20], Kinnard [35], Wendt [60] and Pearson [45]. The original concept of HBU as a process can be linked to the necessity of applying a use premise for valuation in property litigation (specifically condemnation). From there, highest and best use has evolved into other appraisal assignments by relying on legally accepted definitions. Yet despite the legal orientation of HBU employed in many decisions, according to Faust and deSouza [17], the issues of identifying HBU for a parcel of land have their roots in the economic analysis of Von Thunen and Ricardo.

These two distinct analytical origins lead to two conflicting views of HBU. The first view is a site-specific analysis often emphasizing physical and legal attributes (Ricardo); the second is more concerned with a general area or the overall urban structure and relative location (Von Thunen). Colwell [11] classifies these concerns into micro and macro levels. Colwell's stratification identifies two perspectives of the decisionmakers involved in land use. These two general perspectives are the wealth maximization of individuals and the welfare objectives of the community.

The identification of two general conflicts in use analysis, reflecting the level of aggregation and the perspective of the decisionmakers involved, explains why a more broadly accepted land use paradigm has not been employed. The level of the concern (the site or entire area) and the perspective of decisionmakers (individual or community) can be observed as a distinct dichotomy in the literature.

\section{Theoretical Dichotomy}

The appraisal literature emphasizes the specific site analysis and individual wealth maximization, with little or no discussion of macro-location parameters or community objectives. When the broader perspective (area and community) is discussed, the appraisal literature incorporates the community objectives as a constraint on individual options. The societal constraints are often represented by zoning or other political or legal issues. ${ }^{2}$

The urban land economic and urban economic perspective focus on land use within the context of urban structure, avoiding the site-specific issues relevant to appraisal problems. The problem-solving concerns and analytical techniques of the two professions (urban economic and appraisers) and hence their literature tend to break down along the theoretical premises of land use identified by Von Thunen and Ricardo.

\section{Von Thunen Premise}

The economic literature on land use is often divided into the Ricardian or Von Thunen perspectives with the latter dominating. The concern with the spatial issues of economic 
decisions is often presented with a concern for the impact of externalities and accessibility cost on land use decisions. The nature of these externalities and their impact on land use and value are often addressed in the context of specific activities or geographic features in proximity to a given site or neighborhood. These externalities can be classified as either positive or negative. Many authors have discussed the impact of externalities on value, including such factors as the impact of homogeneity of neighborhood and speculation, Hale [28], general amenities, Diamond [15], Krumm [36], a park, Smith [52], visually appealing amenities, Weicher and Zerbst [59], dangerous and unsightly activities (such as a housing project), Guy, Hysom and Ruth [26], access to major transportation corridors, Li and Brown [37] and concentrations of rental properties to single-family housing, Wang [57]. Johnson and Ragas [33] offer a generalized land use/value model incorporating vectors of negative and positive externalites in analyzing land patterns in the CBD of New Orleans.

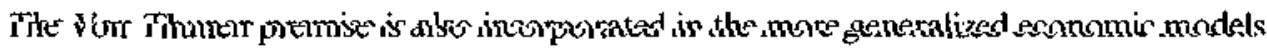
concerned with the macro-location concerns of land use patterns. These generalized urban structure models are divided into social ecologist or rent theorist approaches. ${ }^{3}$ In the first approach, land use is grouped within the context of an overall urban system. The traditional models in this classification are Burgess [9], Hoyt [32] and Farris and Uiliman [29]. These models offer paradigms used to identify land use changes over time and potential directions of city growth. A key insight gained from land use ccology patterns is that surrounding activities influence individual sites and may offer descriptive insights to possible land use changes over time. The land use parameters identified in these siudies are similar to the variables identified in the previously mentioned empirical work such as the impact of proximity to desirable activities, roadways and infrastructure, amenities and competitive, conflicting and supportive land uses.

Therefore the insights of the ecological models can be related to the distance parameter of the rent theorist. Rent theorists offer an analytical land use model that is based on location decisions determined by the distance to a major activity center. The cost of interacting with that center influences the land use and thus the return to the land. Therefore land use is economically determined in the marketplace by the ability of competitive user groups to pay rent for the land, further expanding the basic Von Thunen premise of land use decisions.

The majority of academic urban economic research in use analysis has developed within the Von Thunen framework. Alonso [3] established a partial equilibrium model linking land use to location within the urban structure. The key variables identified in the literature following Alonso, Haig [27], Beckman [8] and other first-generation models is that income expended for location is allocated between site rents and transportation cost. Muth [42], Mils [41], Solow and Vickrey [51] established what Anas and Dendrino term secondgeneration (new) urban economics (NUE) land use models. These models extend the first generation by working towards a general equilibrium approach to land use. The orientation of urban economics towards a general equilibrium model represents a major divergence from the primaty concern of land use decisions in appraisal. As such, the macro issues delineated by Colwell [11] and the societal perspectives of highest and best use might best be relegated to the policy concerns of urban economics while the site-specific use concerns are the domain of appraisal theory.

Much of the second-generation urban economic literature investigating urban structure (macro-land use patterns) is addressed in density models as conducted by Coughlin [13], 
Hendon [31], Glickman [18] and can be used as the basis for understanding external impacts on specific sites (or relative locations). ${ }^{4}$

The general equilibrium models have also examined the behavioral issues of travel behavior and land use associations. The works of Alcary [2], Sirmans [48] and Andrews [6] further influence the external concerns of site-specific accessibility. The accessibility issue has been missing in the appraisal literature on use. In fact, despite the extensive literature on variations of location in the Von Thunen context, few if any of the urban economic location varjables have been directly incorporated into highest and best use analysis.

\section{Ricardian Premise}

An alternative line of research is identified in the appraisal and real estate investment literature. It is more micro-oriented, allowing a comparative approach between alternative sites or property types based on specific site attributes. Ricardo's theoretical influence is evident, because the micro-oriented approach requires an analysis of the physical capacity of the site and the ability of the property to produce returns. Ricardo is often viewed in an agricultural context, with situation value the basis of urban site return. ${ }^{5}$ However, Ricardian oconomics is observed in many urban settings with the generation of marginal physical space tied to the perceived capacity of the site to generate a return. As many oversupplied cities are discovering, the perception of excess returns has brought out much marginal product. This marginal product will be the first to be eliminated from the market supply in a down market.

Ratcliff [46] incorporated the Ricardian concept into use analysis with the discussion of productivity analysis in urban real estate. Ratcliff identified general categories of physical. legal and location attributes as the basis of cost and return to a property's productivity. Alonso [3] also addressed these physical constraints on land use with the consideration of lot size and shape on the market equilibrium. Colwell and Sirmans [12] extended this theme in a more general economic context to address market support based upon size/area and plottage and plattage influences on land use and centrality relationships. As Johnson and Ragas [33] and Smith [52] show, much of the hedonic analysis has complied with Ricardian theory by delineating varying physical features and other plot-specific characterstics that influence land use and pricing issues.

The integration of the location concerns with the physical dimension is often addressed in the literature via legal or property rights issues. The literature on zoning and other land use regulation establishes the framework for the physical and location link in any formulation of a land use model. The regulatory issues are linked to location via the literature on public benefits and infrastructure such as offered by Trebout [53]. Andrews [6], Nourse [43] and Sirmans and Redman [50].

The crux of the legal-location literature suggests that regulations are often based on general physical factors (soil, terrain, infrastructure, water, etc.) and existing or expected land use associations in an area (the potential for supporting land uses, conflicts, etc.). ${ }^{*}$ Alcary [3] has shown that land use regulations often result from the physical features of an area and thus characterize the locational perception of a neighborhood. Consideration of the impact of locational, legal and physical attributes on site productivity is evident in work by Ohls, Weisberg and White [44]. The productivity issues representing the Ricardian

VOLUME 5, NUMBER 1 
premise have set the theoretical framework for the bulk of the appraisal literature. The Appraisal Institute's [4] definition has emphasized a process structured on site-specific attributes of physical, legal and infrastructure dimensions.

Most appraisal literature as witnessed in articles by Albritton [1], Webb [58] and Wendt [60] emphasizes the process of use analysis as an ad hoc site-specific approach and as per Pearson [45], location is not explicitly considered. Implicit consideration of location is incorporated with the issues of externalities and market support, however these issues are not addressed to the extent available in the economic literature.

\section{Integration of the Von Thunen and Ricardian Premises}

For valuation purposes, there is a need for an integration of the Von Thunen and Ricardian premises. These findings support the constrained optimization model constructed by Grissom [23] and the land use production model developed by Pearson [45]. Both of these models enable an analytical investigation of micro-level site use based on Ricardian principles but enable the integration of spatial concerns.

Previous authors have attempted to integrate the site-specific attributes and the macro-level economy of the urban structure. Colwell [11] identified this possibility with the inclusion of the issue of consumer (or investor) surplus, by extending the comparative analysis of the Ricardian model to the macro-analytical level. Vandell [54] has suggested a link of the HBU definition to the bid rent curve of the community. ${ }^{7}$

The economic literature has been more successful in bringing the spatial and site-specific characteristics into synchronization. Grieson and White [22] have investigated the spatial characteristics of zoning, creating a link of site-specific issues to the land use location pattern. Johnson and Ragas [33], by integrating vectors of plot-specific characteristics and external variables, developed a more generalized land use model for value purposes.

The rent theorist models in combination with site-specific characteristics and various behavioral issues have established the theoretical constructs of the hedonic models and empiricism observed in valuation models derived in the later $1970 \mathrm{~s}$ and $1980 \mathrm{~s}$. The empirical and theoretical work during these periods extended the locational framework of Alonso/Von Thunen to include exogenous variables that quantify characteristics such as appropriate support and financial feasibility. Much of this work has identified a concern for capital cost in alternative land use decisions.

Markusen [39] expanded the demand elements of analysis to include issues of capital cost in the land use decision. These costs considered the capital structure. Capital cost issues also appeared in the works of Webb [58], Winger [61] and Graaskamp [20] linking previous research addressing returns, cash flows and profit maximization to the highest and best use decision. Much of this literature can be observed in the practitioners journals in articles by Wendt [59], Webb [58], Grissom [23] and the Appraisal readings [4].

The academic work addressing these concerns can be typified by Sirmans and Redman $[50]$ and Capozza [10] where constant returns to scale from the operations under alternative uses were linked to competitive constraints on production functions, concemed with the substitution of land and non-land factors used in producing the real estate. The introduction of production function models into the land use decision is the juncture in which the locational (Von Thunen theory) dimension and the physical/legal dimension (Ricardian theory) link in the development of the HBU model. 
Alternative approaches illustrating a link between the physical/legal capacity of land units, locational patterns and risk and return issues in a spatial context are offered in several recent papers. The research of Winger [61] and Jones [34] shows a spatial pattern in the pricing and returns of debt capital. Grissom, Hartzell and Liu [24] indicate not only spatial patterns in the returns of industrial property but that geographically diverse market segments price different property attributes differently. This market segmentation partially explains the variation in returns.

The significance of spatially distributed returns are identified by Sirmans and Kau [49] when they suggest the need for a study on the spatial distribution of returns based on distance from the CBD. This suggestion is empirically investigated by MacIntosh and Whitaker [38]. Grissom, Wang and Webb [25] jdentify a spatial clustering of returns when risk as well as return is investigated on a spatial basis. Greenhut [21] offers a general theoretical model of spatial impacts on economic structure that considers not only the return-risk issue on a spatial basis but also the uncertainty that might arise with the conflicts of individual and community objectives. Previous literature supports the cost of capital in a spatial context as an input to the HBU model.

Consideration of the rate structure is important in the integration of the locationally oriented use analysis of the land economic literature and the site-specific concerns of the appraisal literature. The development of a general model, constrained by the social benefit perspective of the community (on the macro-level) and the individual (micro-level) requires the cost of capital to be a criterion explicitly considered.

\section{Integration of the Individual and Community Objectives}

A synthesis of the literature indicates that empirical test and deductive analysis partially support the definition of highest and best use. The decision criteria and constraints ident:fied by the definition of HBU are: legal, physical, market and infrastructure support and financial feasibility. Lacking in this model is the consideration of the cost of capital (in a spatial context) and the interfacing of the individual and community objectives.

As stated earlier, the legal dimension of the realty also introduces the political aspect of the regulatory process. This political element expands the land use decision from the perspective of an individual seeking maximum returns on the site to an issue concerned with the community's objectives. The communal perspective was incorporated into the HBU definition in the 1970s. ${ }^{8}$ This perspective expands the process from a simple optimization model based solely on an individual's opportunity/capital cost to also include choices dependent on the social cost of land use opportunities.

The definition of land use arising out of the $1960 \mathrm{~s} / 1970 \mathrm{~s}$ has been characterized in the works of Goldman and Field [19] and Schwind [47] as issues of Pareto Optimality. This literature established a use analysis within the context of fit between the property owner, the community and non-residents or third parties. This perspective of the land use is also supported by Graaskamp [20] and Kinnard [35]. ${ }^{9}$

The inclusion of social issues in land use decisions requires a major extension to any workable model. The literature offers only normative models stressing issues of economic equity as depicted in the writings of Albritton [1], Nourse [43], Dasso and Woodward [14] and Wunderlich, Gibson and Hildreth [62]. These articles show that the stated objective of 
HBU often result in conflicting constraints and objectives. The conflicts were such that the HBU concept still retained a subjective appearance.

A subjective characterization of land use decisions is exemplified by the definitional statement that HBU is the result of the appraiser's judgment-..-not a fact to be found. This subjectivity in part arises from the lack of a structured model and the problems of specifying the social cost.

Kinnard [35]. Heilbrun [30], Ratcliff [46], Graaskamp [20], Grissom [23] and Pearson [45] have offered theoretical constructs of land use models in various forms that alleviate the subjective element of land use analysis on a site basis. These models use a constrained optimization approach consistent with the definitional criteria of the concept. These definitional criteria establish the standard of the paradigm which can be supported by empirical testing and a priori deductive reasoning observed in the literature.

The definitional criteria are analytically developed in the following section and set the context of the cost of capital model developed in the paper. The significant conclusion of the HBU literature is that the central premise of use analysis is still evolving. The issue of the ominues ovolutions is that in practice only ad hos verhal nrorestes have heen offered to the decision process and the debate will continue until a more concise model is offered to aid the decision process. The purpose of this paper is to develop such a model.

Building on the literature, an appropriate model can be developed using constraints suggested by Barlow [7]. The first stage addresses the issue of the individual user's maximizing process and the second incorporates the impact of community objectives into the decision process. Both of these issues can be incorporated into the cost of capital and modeled as constraints on the integration of the physical, legal and locational parameters.

\section{Highest and Best Use Definitional Criteria}

The definition of highest and best use requires that the use is physically and legally possible, appropriately supported by the public infrastructure and the market and that the use is financially feasible. Essentially, as currently defined, highest and best use analysis is a simulation of a production process. It hypothetically allows for various combinations of legal possibilities and physical improvements to the site. Therefore, the definitional criteria can be incorporated into an objective constrained optimization model integrating the Ricardian and Von Thunen premises into one model.

\section{Locational Constraints}

Although locational parameters are not discussed in the HBU definition, locational differences play a highly significant role in both deternining the economic uses that can be made of land and in affecting rent and value levels associated with those uses..$^{10}$ According to Andrews [6]. location factors can be classified into four categories: (1) accessibility, (2) associations with other land uses, (3) activities currently in the area, and (4) the social, political and economic environment in which the property exists. Locational factors are 
micro factors such as the accessibility of the site, the level of disposable income in the area, and the location of the site relative to major employment centers in the community. As such, they must be considered in the HBU determination, but in a constrained optimization framework they can be assumed to be fixed for all possible uses because the owner of the subject property will be able to exert little influence over these factors in the short run.

Hence the determination of $\mathbf{H B U}$ is reduced to identifying the optimal combination of physical and legal improvements that will maximize the productive capacity of the property to generate net operating income (NOI), given the set of existing locational constraints which are treated as external risk in the cost of capital and as reflected in the income return to the property. See Vandell [54] and Heilbrun [30].

\section{Legal Constraints}

Legal factors such as zoning ordinances, restrictive covenants, building codes and other local ordinances impact the use, and hence the earning capacity, of land. These legal constraints are not fixed, however, because it is possible for any land use limitation to be changed. The cost of changing legal use capacity includes such items as platting fees, engineering fees, transfer of development rights, and the opportunity cost of invested capital during a lengthy rezoning process. The relationship of the cost of obtaining legal changes to permit more valuable uses and the level of NOI associated with such changes are shown in Exhibit la. Point $O$ illustrates that a hypothetical property with no legally permissible uses will not generate any NOI. As the owner expends money seeking changes to permit more intensive and valuable uses, the ability of the property to generate NOI increases. For example, the cost of getting a property zoned agricultural could be represented as point $a$. The level of NOI associated with this use would be $a^{1}$. The cost of getting the site zoned for residential use could be point $b$ and the resulting level of NOI from the residential use would be $b^{\prime}$. Similarly, the cost of getting high density multifamily

\section{Exhibit 1}

(a)

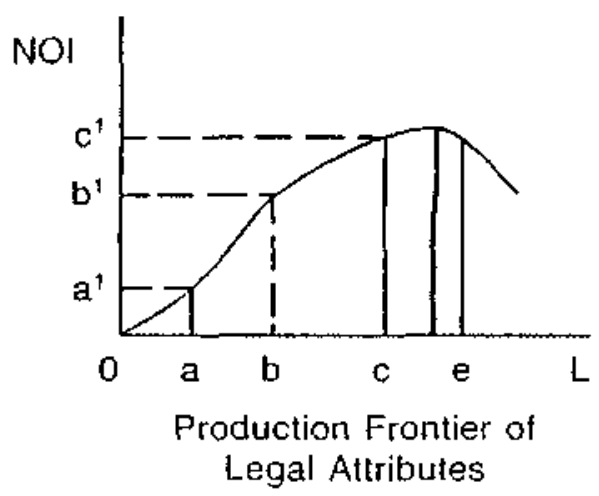

(b)

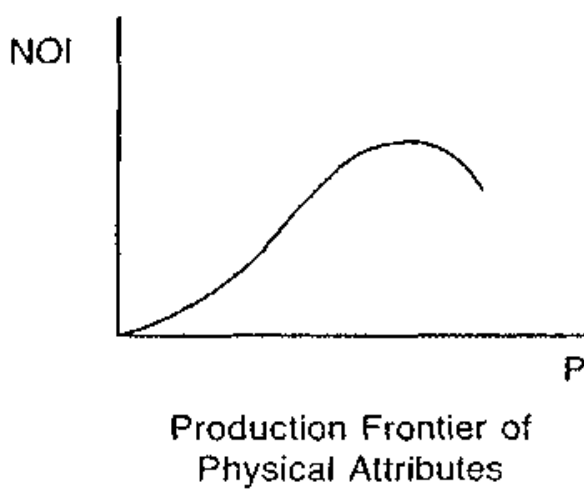


zoning would be point $c$, with resulting NOI of $c^{l}$. The concept of diminishing marginal returns is illustrated in Exhibit la by the fact that expenditures incurred seeking changes for more valuable uses beyond point "e" will result in an actual decline in NOl production. If land use was unrestricted, it is possible that excessive development or inappropriate land usage could actually result in decreasing levels of productivity. Typically called an overimprovement of the land, an example of this might occur when an overzealous developer places so many apartment units on one site that the end result was a lack of parking creating an unpleasant, overcrowded project, resulting in decreased levels of NOI for the site. Other examples include a 4000 S.F. house in a neighborhood of 1500 S.F. houses; a class $\mathrm{A}$ office building on a class $\mathrm{C}$ site and a retail service facility without sufficient parking. All the specific examples illustrate the general condition.

\section{Physical Attributes}

The physical attributes that determine the productive ability of the property to generate NOI are the physical improvements to the site, such as the size, quality and style of the structure, and other site improvements such as parking and landscaping. As illustrated in Exhibit $1 b$, a production frontier exists that maps the relationship of the level of NOI to the amount of physical improvement to the property. The production frontier for physical attributes would be similat to the production frontier for the legal attributes, because

\section{Exhibit 2 \\ Production Frontier of Legal and Physical Inputs}

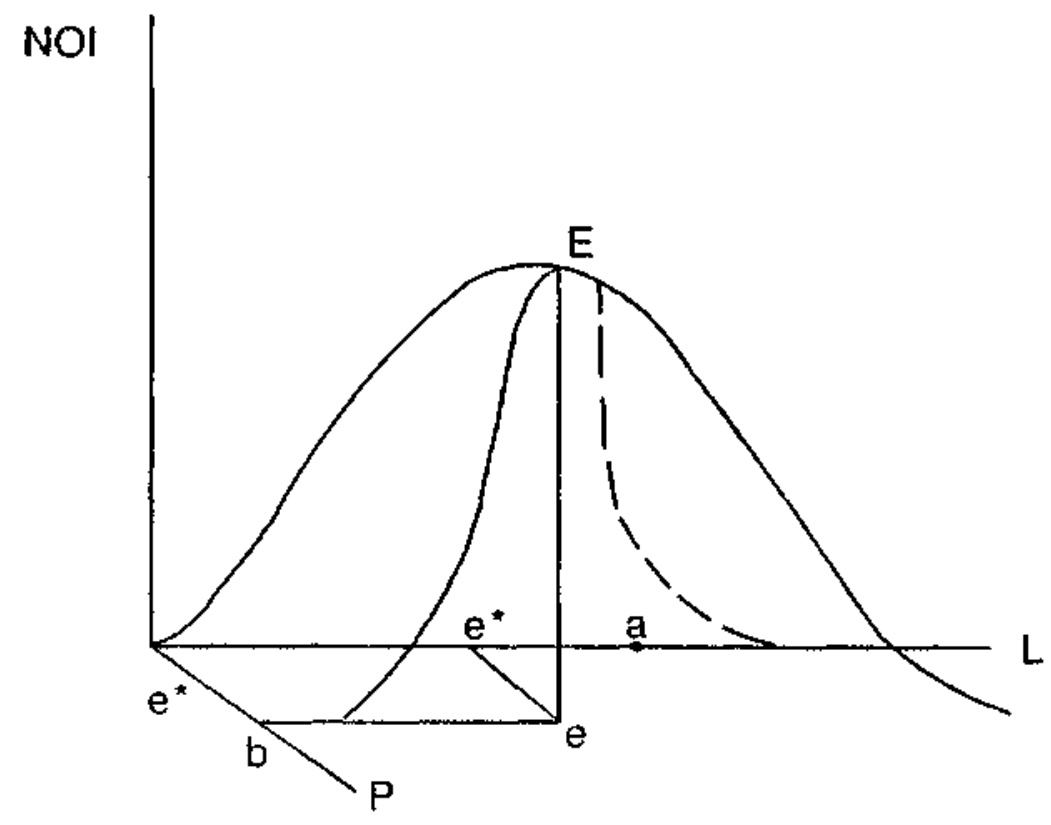


additional expenditures for physical improvements would result in increased levels of NOI, and be subject to the phenomenon of diminishing marginal returns.

As shown, the productive ability of a specific site is a function of legal, physical and locational attributes, and appraisers attempting to identify $\mathrm{HBU}$ of a specific site must consider these three variables. Since the locational factors are considered fixed in the short run, in this example, identification of HBU entails identifying the optimal combination of legal and physical inputs that yield the highest present value.

Conceptually, Exhibit 2 represents the highest and best use decision process as currently defined. Given the current locational attributes of the subject site, the analyst must identify the level of physical improvements and legal capacity that will yield the highest net present value. Assuming a fixed level of locational attributes, the productive possibilities can be represented in the three-dimensional perspective set out in Exhibit 2.

Exhibit 2 illustrates that the level of NOI increases as the amounts of legal and physical inputs are increased. All points on the $L, P$ plane represent various combinations of legal and physical inputs that are theoretically possible. Point a represents the situation where inputs of more valuable legal uses are purchased, but no funds are expended for physical improvement. In the extreme, the property would be unable to generate any income.

Conversely, at point $b$, the property has been physically improved but no legal uses exist, preventing the production of NOI. An example might be a residential property located in an area contaminated with lead or other toxic substances that force governing authorities to prohibit all use of the property.

\section{Exhibit 3}

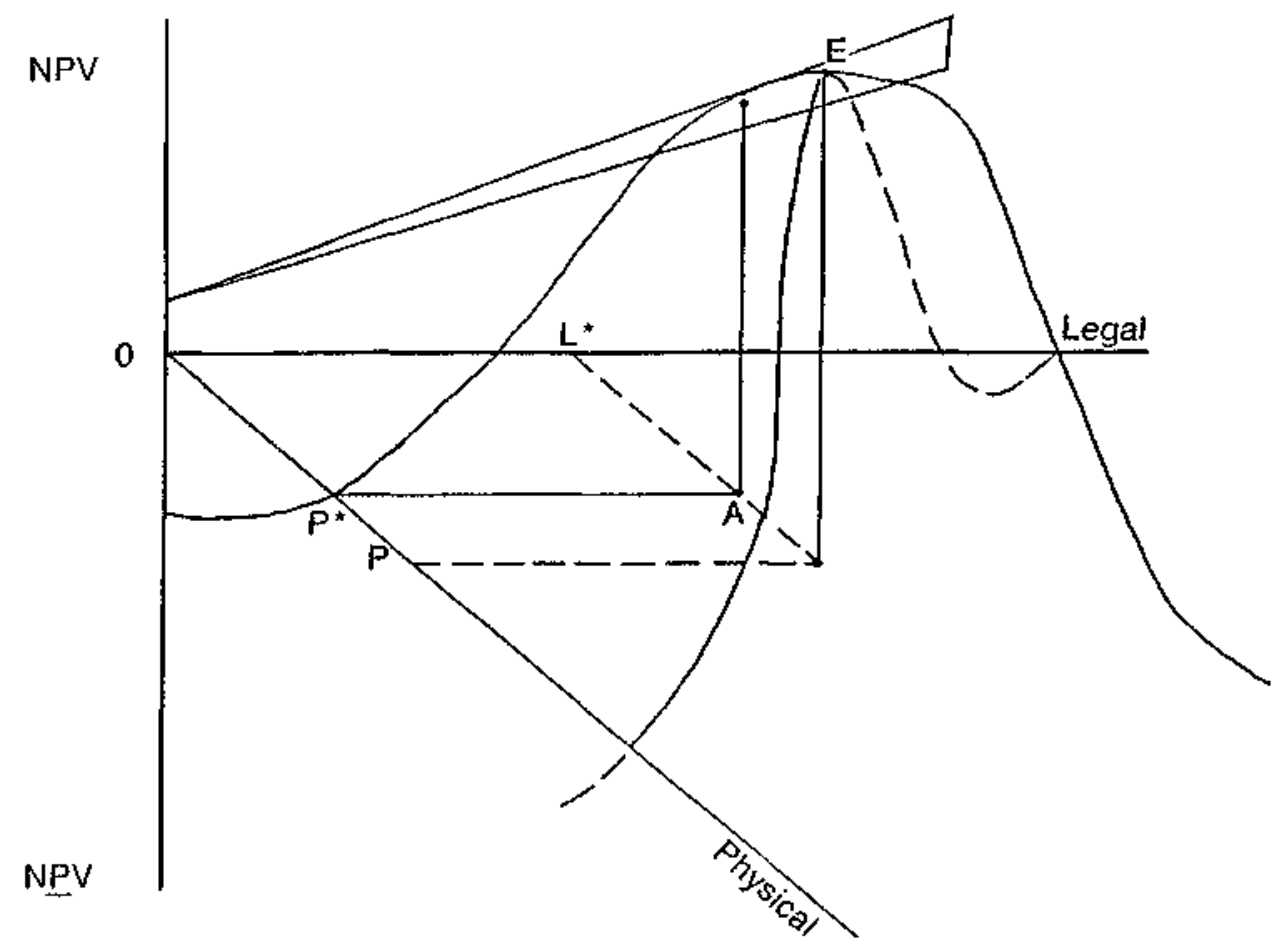

VOLUME 5, NUMBER 1 
In between these two extremes are possible combinations of legal and physical inputs, and the surface over the $\mathrm{L}$. P plane represents the level of productivity (NOI) associated with various combinations of inputs. Point E represents the optimal level of legal-physical input that maximizes a property's NOI. In three-dimensional space, the productivity of the site increases monotonically with each additional dollar invested in legal and physical attributes up to point $E$, which represents the optimal use of the property.

\section{Highest and Best Use Model}

Given the preceding analysis, the HBU concept can be viewed as a constrained optimization problem in which the task is to identify the use that maximizes the net present value of the land, the combination of investment in the site that yields the maximum level of NOI. Point E represents the unconstrained maximum HBU of the site, which is consistent with the current definition of $\mathrm{HBU}$. Notice that additional expenditure for physical/legal improvements results in an actual decline in the productive ability of the site. An example of this situation would be where the property is overdeveloped with a lack of parking and accessibility. Additional development will only result in more overcrowding, traffic congestion and less productive ability to satisfy human needs.

\section{Influence of the Cost of Capital on HBU}

Inherent in the definition of $\mathrm{HBU}$ as the use that supports the highest present value is the time value of money. In the HBU framework, the time value of money can represent the cost of borrowed funds to complete the proposed use, or the opportunity cost of capital on other projects of similar risk as pointed out in the literature. Let $k$ equal the cost of capital in the spatially defined market. This rate is influenced by competitive uses, community objectives and options and the local availability of financial capital.

Given these premises, the discounted cash flow concept can be represented by a plane that has a slope of $(1+k)$ with respect to the $\mathrm{L}$ and $\mathrm{P}$ axes. The presentation of the problem in this manner places the HBU concept in a Fisherian Separation context, with the decision criterion being a trade of alternative property attributes and not a choice of time periods. The point of tangency of the plane and the production opportunity set represents the HBU that maximizes the present value of the property. The optimal land use decision is to

$$
\begin{gathered}
\operatorname{Max}\left[f(P, L, r \mid U) / k_{t, t}\right]-P-L \\
\text { subject to } r=R^{*}
\end{gathered}
$$

where

$P=$ the cost of physical improvements to the site,

$L=$ the cost of securing more valuable legal use for the site,

$r=$ the cost of capital associated with the proposed use, 
$U=$ the surrounding land uses. The surrounding land uses influence the income return potential on a given site. Therefore the income/value function is conditioned on the situs impacts (see Andrews [6], Alonso [3] and the rent theorist),

$k_{y}=$ the capitalization rate (based on the market rate for $j$ type properties) used by $i$ type investors to value the stream of income produced by the site in $t$, a specific location,

$f(P, L, r)=$ the production function that converts the cost of productive inputs into an income return and hence value to an investor,

$R^{*}=$ the appraiser's estimate of the cost of capital associated with the proposed HBU as influenced by capital markets and community pressures. With

$$
R^{*}=f\left(r_{r}, r_{m}, T, t x, c_{r}\right)
$$

where:

$r_{f}=$ the time value or risk-free rate,

$r_{m}=$ the risk premium given the specific market or property use: $r_{n}+\left(r_{f}+r_{m}\right)$,

$T=$ site-specific cost involved in delays as a result of neighborhood associations or planning authorities and other possible third parties that may impact a project without direct involvement,

$t x=$ local tax rate,

$c_{,}=$the community's cost of capital as reftected in municipal bonds and other community debt.

The Lagrangian function illustrates the significance of the cost of capital and the cost of productive inputs in the identification of the HBU that maximizes the net present value of the site use.

The Lagrangian function can be stated as:

$$
H=f(P, L, r \mid U) / k_{t \prime}-L-P-v\left(r-R^{*}\right) .
$$

Taking the first-order conditions of the Lagrangian yields:

$$
\begin{gathered}
d H / d P=D P / k_{t y}(r)-1=0 \\
d H / d L=D L / k_{t, h}(r)-1=0 \\
d H / d r=D r / k_{m}=0 \\
d H / d v=r-R^{*}=0
\end{gathered}
$$

Rewriting (4), (5) and (7) reveals the optimal level of use (HBU) condition.

$$
\begin{gathered}
D P / k_{w}=1 / r \\
D L / k_{w}=1 / r \\
r=R^{*}
\end{gathered}
$$


First-order condition (8) shows that the optimal level of physical inputs is achieved when the marginal cost of an additional dollar of input equals the marginal revenue associated with the additional expenditure. Equation (9) shows that the same optimal condition holds for legal attributes as well. The first-order conditions indicate that the maximum level of NPV (hence the highest and best use of the property) occurs where the marginal costs of the inputs equals the marginal revenue of the inputs which equals the opportunity cost of capital associated with the proposed use. The highest and best use of the property is that use which combines input combinations of physical and legal attributes in quantities such that the marginal revenue product of the physical attributes equals the marginal revenue product of the legal attributes and the cost of capital for a given use. The HBU is shown graphically in Exhibit 3 as point A, which represents the highest productive value of input combination $\left(\mathrm{L}^{*}, \mathrm{P}^{*}\right), \mathrm{L}^{*}$ and $\mathrm{P}^{*}$ are the optimal amount of legal and physical attributes that would produce the maximum net present value, given the fixed locational attributes of the property. At this optimal level, the marginal revenue from additional physical and legal inputs equals the marginal cost and the opportunity cost of capital. Notice that point $A$ represents the combination of $\left(L^{*}, \mathrm{P}^{*}\right)$ which is less intensely developed than point $\mathrm{E}$. At point $\mathrm{A}$ the marginal increase in value of additional physical improvement is equal to the marginal increase in value of additional lcgal opportunity. The incremental gains in the physical and legal attributes are equal to the opportunity cost of capital. Any additional expenditure for physical or legal inputs will result in a decline in the net present value of the property.

Suppose that the cost of capital increases from $K$ to $(K+x)$, where $x$ is a positive percentage. The increase in the discount rate will cause the slope of the cost of capital plane to increase. The optimal amount of physical and legal inputs decline to the point where the marginal revenue of the physical and legal inputs equals the higher cost of capital. An example of this would be a situation where the appraiser estimates that the HBU of a property (at interest rate $K$ ) is an office complex with a racquetball court and health club. However, when rates increased to $K+x$, the office complex still is the HBU but the racquetball/club is no longer justified (i.e., the marginal return associated with the racquetball/club is less than the cost of capital).

\section{Summary and Conclusion}

This article has illustrated that despite the eclectic concerns of land use issues and their two distinct theoretical premises as posited in the literature, the operational definition of HBU represents a constrained optimization problem where the appraiser attempts to identify the optimal combination of physical, legal, locational and capital attributes that maximize the wealth of the owner. As such. HBU can then be quantitatively identified to occur where the marginal revenue product (additional value) associated with the next dollar spent for both legal and physical improvements will equal the marginal cost of these inputs, and the cost of capital. Applications of the model's components were illustrated in numerous examples within the article. Future research must address a more aggregative approach with empirical support. 


\section{Notes}

${ }^{1}$ See a collection of readings on highest and best articles complied by The American Institute of Real Estate Appraisers (AIREA), Readings in Highest and Best Use (AIREA: Chicago, 1981).

${ }^{2}$ The societal constraints. especially as established by zoning and political/legal constraints, are covered in the AIREA readings and articles such as J. C. Ohls, R. C. Weisberg and M. J. White [44].

Walters [56] identifies the social ecologist and rent theorist as two distinct schools on urban structure thought; Alonso [3] supports this delineation.

${ }^{4} T$ The link between these models and the appraisal HBU premise is the improvement in the process promulgated by Vandell [54].

'Marshall [40] initially addressed the comparative situation (location) between individual sites as the basis of value. This is related to the Ricardian format of comparison between specific or individual sites (a micro-perspective). The Ricardian format is an analytical process: It is not limited to a concern only for the physical attributes of a property.

'See the entire issue of $A R E U E A$ Journal on land development regulation and ecology, AREUEA Journal 9:4 (Winter 1981). See the introduction by Hugh Nourse.

${ }^{7}$ Heilbrun [30] has achieved this extension in a graphical presentation linking the community's bid rent curve to the cost curves of competitive sites. The comparison is achieved in a Ricardian context.

${ }^{8}$ There are a series of articles and books on this topic identified in the research of Graaskamp [20] and Grissom [23].

"This issue is addressed in Graaskamp's format for "The Real Estate Process." Charles Wurtzebach has addressed the format as the Development Process.

${ }^{10}$ See the economic literature on the Von Thunen premise.

\section{References}

[1] Harold Albrition. Testing Highest and Best Use. The Apprasal Journal 47:3 (July 1979), 406-11.

[2] Roger E. Alcary. Transportation and Urban Land Values: A Revew of the Theoretical Literature. Land Economics 52:1 (February 1976), 4253.

[3] William Alonso. Location and Land Use. Cambridge: Harvard University Press, 1964.

[4] American Institute of Real Estate Appraisers (AIREA). Readings in Highest and Best Use. Chicago. AIREA. 1981.

[5] Alex Anas and Dimitrios Dendrino. The New Urban Economics. A Brief Survey. In Mathematical Land Use, 23 52. Lexington, Mass.: D. C. Heath, Lexington Books, 1976.

[6] Richard B. Andrews. Urban Land Economics and Public Policy, Ch. 2. New York: The Free Press, Collier MacMillan Limited, 1971.

[7] Raleigh Barlow. Land Resource Economics. Englewood, N.J.: Prentice-Hall, fourth edition 1986.

[8] M. I. Beckman, Von Thunen Revisited: A Neoclassical Land Use Model. The Swedish Journal of Economics 74 (1972), 1.7.

[9] E. W. Burgess. The Growth of the City. In The City. Chicago: University of Chicago Press, 1925.

[10] Dennis R. Capozza. Forecasting Long-Run Land Use Patterns with an Aggregative Model of Urban Housing and Transportation: The Case for Los Angeles. AREUEA Journal 4:1 (Spring 1976), 23-39.

VOLUME 5, NUMBER 1 
[11] Peter Colwell. Highest and Best Use: Is it a Micro or a Macro Concept? Office of Real Estate Research, University of lltinois, ORER Lether (Fall 1988), 13.

[12] —- and C. F. Sirmans. Area. Time, Centrality and the Value of Urban Land. Land Economics 54:4 (November 1978), 514-19.

[13] Robert E. Coughlin, Municipal Costs and Reventes. Wetlesley, Mass.: Chandler-Davis. 1957.

[14] Jerome Dasso and Lynn Woodward. Real Estate Education: Past, Present and Future--.-The Search for a Discipline. AREUEA Jotrnal 8:4 (Winter 1980), 404-16.

[15] Douglas B. Diamond Jr. The Relationship Between Amenities and Urban Land Prices. Land Economics 56:1 (February 1980), 2132.

[16] J. D. Eaton. Real Estate Vahation in Litigation. Chicago: AIREA. 1982.

[17] J. Brady Foust and Anthony R. deSouza. The Economic Landscape A Theoretical hiroduction, 41 42. Columbus, Ohı: Charles E. Merrill Publishing Co., 1978.

[18] Norman Glıckman. An Econometric Forecasting Model for the Philadelphia Regıon. Journal of Regional Science II (1971). 15.32.

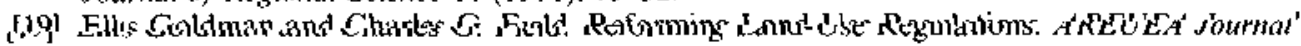
11:2 (Summer 1983), 300-18.

[20] James A. Graaskamp. The Appraisal of 25 North Pinckney. Madison, Wisc: Landmark Publishers. 1979.

[21] Melvin L. Greenhut. A Theory of the Frm in Economic Space. Austin, Tex.: Austin Press, 1974.

[22] Ronald Grieson and L. M. White. The Supply of Rental Housing: Comment. American Economic Revien 55 (1973), 433-36.

[23] Terry V Grissom. The Semantics Debate Highest and Best Use vs. Mosi Probabie Use. Appraisal Journal 51:1 (January 1986), 4557.

[24] A.... David Hartzell and Crocker Liu. An Approach to Industrial Real Estate Market Segmentation and Valuation Using the Arbitrage Pricing Paradigm. AREUEA Journal 15:3 (Fall 1987), 199-219.

[25] _ - . Ko Wang and James Webb. The Spatial Equilibrium of Intra-Regional Rates-ofReturn and the Implications for Real Estate Portfolio Diversification. Paper presented at the AREUEA meetings in New York, 1988.

[26] Donald C. Guy, John L. Hysom and Stephen R. Ruth. The Effect of Subsidized Housing on Values of Adjacent Housing. AREUEA Journal 13:4 (Winter 1985), 37887.

[27] Robert Murray Haig. Toward an Understanding of the Metropolis. The Quarterly Journal of Econonics (February 1926), 179-208 and (May 1926), $402-34$.

[28] Cart W. Hale. Impact of Technological Change on Urban Market Areas, Land Values, and Land Use. Land Economics 49:3 (August 1973), 351-55.

[29] C. D. Harris and E. L. Ullman. The Nature of Cities. The Annals of the American Academy of Polincal and Soctal Science 5 (1945), 7-17.

[30] James Heilbrun. Urhan Econonics and Public Polny. New York: St. Martin`s Press, 1974.

[3]] W. S. Hendon. Property Value, Schools, and Park-School Combinations. Land Economics 49:2 (May 1973), 216-18.

[32] Homer Hoyt. Recent Distortions of the Classical Models of Urban Structure. Land Economics 40:2 (May 1964), 199-21I.

[33] Michael S. Johnson and Wade R. Ragas. Central Business District Land Value. Land Economics 63:4 (November 1987), 337-47.

[34] Ted C. Jones. Systematic Differences in Interest Rates for Conventional Fixed-Rate Residential Mortgage Loans Across Select U.S. Cities 1980 83. Dissertation, Texas A\&M University, July 1985.

[35] William Kinnard. New Thinking in Appraisal Theory. The Real Essate Appraiser 32:8 (Augus1 [966), 6-10.

[36) R. J. Krumin. Neighborhood Amenit1es: An Economic Analysis. Journal of Urhan Economics $7(1980), 208 \cdot 24$.

[37] Mingche M. Li and $\mathrm{H}$. James Brown. Micro-Neighborhood Externalities and Hedonic Housing Prices. Land Economics 56:2 (May 1980), 125-41.

[38] Willard MacIntosh and J. C. Whitaker. The Stability of Market Extracted Overall Capitalization Rates. Paper presented at ARES meetings, Washington D.C., 1989. 
[39] James R. Markusen. Elements of Real Asset Pricing: A Theoretical Analysis with Special Reference to Urban Land Prices. Land Economics 55:2 (May 1979), 152-66.

[40] Alfred Marshall. Principles of Economics. New York: Macmillan, ejghth edition 1979.

[41] E. S. Mills. Markets and Efficient Resource Allocation in Urban Areas. The Swedish Journal of Economics 74 (1972), 100-13

[42] R. F. Muth. Cities and Housing. Chicago: University of Chicago Press, 1969.

[43] Hugh O. Nourse. Implications from Land Use, Best Use, and Consumer Ethics (Highest and Best Use to Whom?). In 1984 Real Estate Valuatton Colloquium, 111-23. Boston: Oelgeschlager, Gaun and Hain (Lincoln Institute Land Policy Book), 1986.

[44] J. C. Ohls, R. C. Weisberg and M. J. White. The Effects of Zoning on Land Value. Journal of Urban Economics I (1974), 428-44.

[45] Thomas Pearson. A Microeconomic Framework for the Analysis of Highest and Best Use. Presented at the American Real Estate Society meetings, Denver, October 1985.

[46] Richard U. Ratcliff. Valuation for Real Estate Decisions. Santa Cruz, Calif.: Democrat Press, 1972.

[47) Paul J. Schwind. The Evaluation of Land Use Alternatives: A Case Study of the Metropolitan Fringe of Honolulu, Hawaii. Latd Economics 53:4 (November 1977), 410-22.

[48] C. F. Sirmans. An Econometric Analysis of Urban Travel Behavior between Residence and Work Site. AREUEA Journal 4:2 (Fall 1976), 19-32.

[49] - -...- and James Kau. Changes in Urban Land Values: 1830. 1970 Journal Of Urban Economics 15 (1984), 18 25 .

[50] C. F. Sirmans and Arnold Redman. Capital-Land Substitution and the Price Elasticity of Demand for Urban Residential Land. Land Economics 53:2 (May 1979), 167-76.

[51] R. M. Solow and W. S. Vickrey. Land Use in a Long Narrow City. Joumal of Economic Theory 3 (December 1971), 430-47.

[52] Barton Smith. Measuring the Value of Urban Amenities. Journal of Urban Economics 5 (July 1978), 370-87.

[53] Charles M. Tiebout. A Pure Theory of Local Expenditures. Journat of Political Economy 64 (October 1956), 416.24.

[54] Kerry D. Vandell. Toward Analytically Precise Definitions of Market Value and Highest and Best Use. The Appraisal Joumal 50.2 (April 1982), 253-68.

[55] Johann H. Von Thunen. Der Isolierte Staat in Beziehung auf Landwirtschaft und Nationalekonomie, 1st Vol. Hamburg: 1826 (translation by Carla M. Wartenberg as the Isolated Siate, Pergamon Press, 1966).

[56] G R. Walters. Urban Land and the Environment: The Physical and Social Dimensions. Recent Perspectives in Urban Land Economics, 28-41. Vancouver: University of British Columbia, 1976.

[57] Ko Wang. The External Impacts of Rental Properties on the Price of Single-Family Residences. Dissertation, University of Texas, Austio. 1988.

[58] James R. Webb. Highest and Best Use: An Actual Re-examination. The Appraisal Journal 48: I (January 1980), 57-63.

[59] John C. Weicher and Robert H. Zerbst. The Externalities of Neighborhood Parks: An Empirical Investigation. Land Economics 49:1 (February 1973), 99-105.

[60] Paul F. Wendt. Highest and Best Use-Fact or Fancy? The Appraisal Journal 40:2 (Apri] 1972). $165 \cdots 74$.

[61] Alan R. Winger. Regional Growth Disparities and the Mortgage Market Journal of Finance (1969), 659-62.

[62] Gene Wunderlich, W. L. Gibson and R. J. Hitdreth. Merhods for Land Economic Research, 1-17. Lincoln. Neb.. Unıversity of Nebraska Press, 1966. 